\title{
Relationship Between the Presence of Mental Retardation in Pediatric Patients Undergoing Elective Surgery and Preoperative Parent's Anxiety
}

\author{
(1) Yunus Emre Celep, (1) Serdar Demirgan, (1) Funda Gümüş Özcan, (1) Ayşin Selcan \\ University of Health Sciences Turkey, Bağcılar Training and Research Hospital, Clinic of Anesthesiology and Reanimation, istanbul, Turkey
}

\section{Abstract}

Objective: The care of pediatric patients with mental retardation (MR) who will undergo surgery for families may become complex and stressful. This study aimed to investigate the effect of MR grade on the anxiety of parents of pediatric patients who will undergo surgery under general anesthesia.

Methods: The parents of 40 pediatric patients with group MR and 60 pediatric patients with normal mental state (group NMS) who underwent surgery under general anesthesia were subjected to preoperative State-Trait Anxiety Inventory (STAI) test. In addition to parents' demographic data, such as age, sex, educational status, occupational status, and consanguineous marriages, the effect of sex and MR grade of children on anxiety was examined.

Results: The patient's demographics showed nonsignificant differences. No significant difference was found between the parents of the two groups in terms of SAI and TAI scores. Similarly, parental occupation, education level, and sex of the child had no effect on the SAI and TAI scores. The presence of consanguineous marriages was significantly higher in group MR. In group NMS, a significant positive correlation was found between SAI and TAI scores of the parents.

Conclusion: No correlation was found between the presence and MR grade of the child and parents' SAI and TAI scores. Therefore, no relationship was found between MR in children and parental anxiety levels.

Keywords: Parental anxiety, mental retardation, pediatric anesthesia, minor surgery, State-Trait Anxiety Inventory

\section{INTRODUCTION}

Anxiety is a normal part of life. It allows us to be prepared to deal with daily problems, to make quick decisions in case of danger, and to avoid dangerous situations. Normally, this type of anxiety is mild and manageable (1). By contrast, excessive anxiety adversely affects daily life and even prevents an individual from continuing their normal activities.

Parents normally feel anxious when their children undergo surgery (2). Anxiety may develop in patients and/or parents in the preoperative period due to different reasons, such as fear of inability to wake up or of death after anesthesia, fear of loss of control, pain, isolation, separation from parents and separation from social life (3). Anxiety affects not only individuals who will undergo surgery, but also their family members (4).

Concerns about anesthesia and surgical intervention adversely affect surgery and postoperative recovery (5). Preoperative anxiety, postoperative behavior, and family anxiety are interconnected concepts that have gained great importance in recent years (6). Anesthesiologists are interested in the parents' emotional state as much as their patient's emotional state (7). Preoperative preparation of pediatric patients and prevention

Cite this article as: Celep YE, Demirgan S, Gümüș Özcan F, Selcan A. Relationship Between the Presence of Mental 
of anxiety are important parts of pediatric anesthesia. Anxiety in pediatric patients may cause negative postoperative behaviors, such as nightmares, isolation anxiety, eating disorders, and enuresis, and children's anxiety increases with the increase in parental anxiety (8). In the preoperative period, children and their parents should be psychologically evaluated together. The better the parents are prepared and informed in the preoperative period, the more they can help their children.

The care of pediatric patients with mental retardation (MR) is difficult in the normal period, and the management of the general condition of these children who will undergo surgery for families may become more complex. This may cause higher anxiety levels in families. In the literature, no study compared the preoperative anxiety levels of parents of children with MR and those of parents of children with normal mental state (NMS).

Therefore, this study aimed to investigate the effect of MR of pediatric patients who will undergo minor surgery under general anesthesia on parental anxiety. In addition, the association between demographic data, such as age, sex, education level, and occupation, and anxiety level were investigated.

\section{METHODS}

Our study was conducted in the operating room of the University of Health Sciences Bağcılar Training and Research Hospital after the approval of the Clinical Research Ethics Committee (decision no: 2018.05.02.049) and obtaining the written informed consent of all participating individuals. Parents of 40 pediatric patients with MR (group MR) and 60 pediatric patients with NMS (group NMS) who underwent elective surgery under general anesthesia in our hospital were subjected to State-Trait Anxiety Inventory (STAI) test. Parents who were illiterate or refused to fill out the questionnaire were excluded. Parents of children who had no history of operation under general anesthesia, who would be operated under elective conditions, and who were accepted in pediatric age group according to their developmental stages as younger than 18 years were included.

The children were administered $0.5 \mathrm{mg} / \mathrm{kg}$ midazolam orally 15 minute before admission to the operating room. Parents were allowed to answer questions without being influenced and in a calm environment. The demographic data of the parents, such as age, education, occupation, presence of consanguineous marriage, and age and sex of the child were recorded. The parents who participated in the study underwent STAI test preoperatively. The SAI and TAI scores of the parents in groups MR and NMS were compared. Correlations between the SAI and TAI scores of the parents were investigated. The effect of sex, parental occupation and educational status, and MR grade (mild, moderate, severe), determined by the child's medical report, on the SAI and TAI scores were also evaluated.

\section{Statistical Analysis}

Statistical analysis was performed with Number Cruncher Statistical System 2007 Statistical Software (Utah, USA). In the evaluation of data, in addition to descriptive statistical methods (mean, standard deviation), One-Way analysis of variance was used for comparisons between groups with normal distribution, independent t-test for comparison of two groups, chi-squared test for comparison of qualitative data, and Pearson correlation test to determine the relationships between variables. Moreover, $p<0.05$ was considered statistically significant.

\section{RESULTS}

The study included 100 patients, including the parents of 40 pediatric patients with MR (group MR) and parents of 60 pediatric patients with NMS (group NMS) were included in the study. Table 1 shows the demographic data of the groups. The rate of consanguineous marriages was significantly higher in group MR ( $p=0.02$ ). No significant difference was found in the demographic data between the groups (Table 1).

No statistically significant difference in the mean SAI and TAI scores was found between the parents of both groups $(p>0.05$; Table 2).

Based on the child's sex, no effect was found on the SAI and TAI scores of the mother $(p=0.099 ; p=0.940)$ and father $(p=0.294$; $p=0.643$ ) in group MR. Similarly, no statistically significant difference was found in the SAI and TAI scores of the mother $(p=0.633 ; p=0.576)$ and father $(p=0.930 ; p=0.365)$ in group NMS. With regard to the educational level of the parents, no significant differences were found in the SAI and TAI scores of the parents of both groups ( $p>0.05)$. With regard to the parents' occupation, no significant difference was found in both scale scores of the parents in both groups $(p>0.05)$. No statistically significant difference was found between the mean SAI and TAI scores of the parents and MR grade (mild, moderate, severe) of the patients in group MR ( $p>0.05$; Table 3$)$.

No statistically significant correlation was found between the mean SAI and TAI scores of the parents in group MR ( $p>0.05)$. A statistically significant positive correlation was found between the mean SAI and TAI scores of the parents in group NMS, suggesting that parents in this group contribute to each other's anxiety in the preoperative period (Table 4). 


\begin{tabular}{|c|c|c|c|c|}
\hline & & Group MR $(n=40)$ & Group NMS $(n=60)$ & $\mathrm{p}$ \\
\hline \multicolumn{5}{|l|}{ Mother } \\
\hline Age & & $39.92 \pm 8.72$ & $37.55 \pm 5.83$ & 0.109 \\
\hline Education & $\begin{array}{l}\text { Literate } \\
\text { Primary school } \\
\text { High school } \\
\text { University }\end{array}$ & $\begin{array}{l}4(10.00 \%) \\
24(60.00 \%) \\
10(25.00 \%) \\
2(5.00 \%)\end{array}$ & $\begin{array}{l}0(0.00 \%) \\
36(60.00 \%) \\
18(30.00 \%) \\
6(10.00 \%)\end{array}$ & 0.073 \\
\hline Occupation & $\begin{array}{l}\text { Housewife } \\
\text { Government employee } \\
\text { Self-employment } \\
\text { Employee }\end{array}$ & $\begin{array}{l}36(90.00 \%) \\
2(5.00 \%) \\
0(0.00 \%) \\
2(5.00 \%)\end{array}$ & $\begin{array}{l}47(78.33 \%) \\
5(8.33 \%) \\
2(3.33 \%) \\
6(10.00 \%)\end{array}$ & 0.414 \\
\hline \multicolumn{5}{|l|}{ Father } \\
\hline Age & & $43.78 \pm 9.3$ & $41.42 \pm 5.26$ & 0.116 \\
\hline Education & $\begin{array}{l}\text { Primary school } \\
\text { High school } \\
\text { University }\end{array}$ & $\begin{array}{l}21(52.50 \%) \\
16(40.00 \%) \\
3(7.50 \%)\end{array}$ & $\begin{array}{l}20(33.33 \%) \\
30(50.00 \%) \\
10(16.67 \%)\end{array}$ & 0.121 \\
\hline Occupation & $\begin{array}{l}\text { Government employee } \\
\text { Self-employed } \\
\text { Employee } \\
\text { Unemployed } \\
\text { Retired }\end{array}$ & $\begin{array}{l}2(5.00 \%) \\
19(47.50 \%) \\
15(37.50 \%) \\
1(2.50 \%) \\
3(7.50 \%) \\
\end{array}$ & $\begin{array}{l}10(16.67 \%) \\
26(43.33 \%) \\
23(38.33 \%) \\
1(2.50 \%) \\
0(0.00 \%)\end{array}$ & \\
\hline Consanguineous marriages & $\begin{array}{l}\text { No } \\
\text { Yes }\end{array}$ & $\begin{array}{l}26(65.00 \%) \\
14(35.00 \%)\end{array}$ & $\begin{array}{l}51(85.00 \%) \\
9(15.00 \%)\end{array}$ & $0.02 *$ \\
\hline \multicolumn{5}{|l|}{ Children } \\
\hline Age & & $10.5 \pm 3.78$ & $9.58 \pm 3.01$ & 0.182 \\
\hline Gender & $\begin{array}{l}\text { Male } \\
\text { Female }\end{array}$ & $\begin{array}{l}26(65.00 \%) \\
14(35.00 \%)\end{array}$ & $\begin{array}{l}35(58.33 \%) \\
25(41.67 \%)\end{array}$ & 0.503 \\
\hline
\end{tabular}

\begin{tabular}{|l|l|l|l|}
\hline \multicolumn{4}{|c|}{ Table 2. Parental state and trait anxiety inventor scores } \\
\hline & $\begin{array}{l}\text { Group MR } \\
(\mathbf{n}=\mathbf{4 0})\end{array}$ & $\begin{array}{l}\text { Group NMS } \\
(\mathbf{n}=60)\end{array}$ & $\mathbf{p}$ \\
\hline $\begin{array}{l}\text { Mother's SAI, median } \\
\text { (min-max) }\end{array}$ & $54.5(31-72)$ & $56.5(31-75)$ & 0.987 \\
\hline $\begin{array}{l}\text { Mother's TAI, median } \\
\text { (min-max) }\end{array}$ & $46(33-64)$ & $48(33-62)$ & 0.344 \\
\hline $\begin{array}{l}\text { Father's SAI median } \\
\text { (min-max) }\end{array}$ & $46.5(30-70)$ & $45(28-76)$ & 0.506 \\
\hline $\begin{array}{l}\text { Father's TAI, median } \\
\text { (min-max) }\end{array}$ & $39.5(25-56)$ & $40(32-73)$ & 0.906 \\
\hline $\begin{array}{l}\text { Independent t-test, SAI: State Anxiety Inventory, TAI: Trait Anxiety Inventory, MR: } \\
\text { Mental retardation, NMS: Normal mental state, Min: Minimum, Max: Maximum }\end{array}$ \\
\hline
\end{tabular}

\section{DISCUSSION}

In our study, the STAI test was applied to the parents to evaluate the effect of MR in children who underwent minor surgery with general anesthesia on parental anxiety. The study results showed Table 3. Distribution of State and Trait Anxiety Inventory scores according to mental retardation grade

\begin{tabular}{|l|l|l|l|l|}
\hline & $\begin{array}{l}\text { Mild mental } \\
\text { retardation }\end{array}$ & $\begin{array}{l}\text { Moderate } \\
\text { mental } \\
\text { retardation }\end{array}$ & $\begin{array}{l}\text { Severe } \\
\text { mental } \\
\text { retardation }\end{array}$ & $\mathbf{p}$ \\
\hline $\begin{array}{l}\text { Mother's SAI } \\
\text { Median } \\
\text { (min-max) }\end{array}$ & $\begin{array}{l}56 \\
(41-72)\end{array}$ & $\begin{array}{l}53 \\
(31-71)\end{array}$ & $\begin{array}{l}59.5 \\
(48-66)\end{array}$ & 0.292 \\
\hline $\begin{array}{l}\text { Mother's TAI } \\
\text { Median } \\
\text { (min-max) }\end{array}$ & $\begin{array}{l}47 \\
(33-61)\end{array}$ & $\begin{array}{l}46 \\
(36-59)\end{array}$ & $\begin{array}{l}53.5 \\
(43-64)\end{array}$ & 0.256 \\
\hline $\begin{array}{l}\text { Father's SAI } \\
\text { Median } \\
\text { (min-max) }\end{array}$ & $\begin{array}{l}47 \\
(30-70)\end{array}$ & $\begin{array}{l}46 \\
(33-64)\end{array}$ & $\begin{array}{l}50 \\
(38-68)\end{array}$ & 0.282 \\
\hline $\begin{array}{l}\text { Father's TAI } \\
\text { Median } \\
\text { (min-max) }\end{array}$ & $\begin{array}{l}39 \\
(25-54)\end{array}$ & $\begin{array}{l}40 \\
(30-52)\end{array}$ & $\begin{array}{l}41 \\
(38-56)\end{array}$ & 0.248 \\
\hline $\begin{array}{l}\text { SAl: State Anxiety } \\
\text { Maximum }\end{array}$ & Inventory, TAI: Trait Anxiety Inventory, Min: Minimum, Max: \\
\hline
\end{tabular}


Table 4. Evaluation of correlation between State and Trait Anxiety Inventory scores of parents

\begin{tabular}{|c|c|c|c|}
\hline \multicolumn{2}{|l|}{ Group } & SAI (Mother) & TAI (Mother) \\
\hline Group MR SAI (father) & $\begin{array}{l}r \\
p\end{array}$ & $\begin{array}{l}-0.067 \\
0.680\end{array}$ & $\begin{array}{l}-0.048 \\
0.768\end{array}$ \\
\hline Group MR TAI (father) & $\begin{array}{l}r \\
p\end{array}$ & $\begin{array}{l}-0.119 \\
0.245\end{array}$ & $\begin{array}{l}-0.169 \\
0.298\end{array}$ \\
\hline Group NMS SAI (father) & $\begin{array}{l}r \\
p\end{array}$ & $\begin{array}{l}0.288 \\
0.025\end{array}$ & $\begin{array}{l}0.252 \\
0.052\end{array}$ \\
\hline Group NMS TAI (father) & $\begin{array}{l}r \\
p\end{array}$ & $\begin{array}{l}0.145 \\
0.270\end{array}$ & $\begin{array}{l}0.257 \\
0.048\end{array}$ \\
\hline $\begin{array}{l}\text { Pearson correlation test } \\
\text { SAI: State Anxiety Inventory, } \\
\text { NMS: Normal mental state }\end{array}$ & & nventory, MR & tal retardation, \\
\hline
\end{tabular}

significant relationship was found between the presence of MR and consanguineous marriage.

Children undergoing surgery is a serious cause of anxiety for families. In the preoperative period, worries related to surgery and anesthesia cause anxiety in patients and their relatives, and this may lead to negative effects in the patient. Sime (9) reported that high anxiety level prolongs hospital stay, necessitates a higher dose of analgesics and sedatives, and increases the risk of postoperative complications. The anxiety of the parents, especially the mothers, contributes to the anxiety of children before they undergo surgery. The care of pediatric patients with MR is already difficult in the normal period, and it may be more difficult for families to manage their general condition preoperatively. This study aimed to compare the anxiety level of parents of pediatric patients with MR with those of pediatric patients with NMS. The literature reports variable results regarding the relationship between parent and child age with preoperative anxiety levels. Many studies reported that parental age has no effect on anxiety level (10-12). In a study investigating the relationship between maternal anxiety and child age, mothers of children younger than 1 year had higher anxiety levels (5). Güner et al. (13) obtained different results in their study, and no significant difference was observed in the anxiety level of parents when compared according to the age of the child. Because of the similar mean age of children and parents of the two groups, we speculate that these two variables did not affect our study results. In a study conducted in parents of children $\geq 2$ years, the Beck anxiety scores were high, and no significant difference was found in STAI. In the same study, SAI scores were higher in the parents of girls compared with those of boys (14). In our study, no statistically significant difference was found between boys and girls in terms of parental anxiety.
This difference between studies may be due to the different regions where the studies were conducted. In our country, cultural differences in different regions may cause changes in attitudes depending on the child's sex. Although no difference was observed in sex-related attitudes in some regions, girls or boys are given more importance or girls are more protected in some regions. Many studies have reported that anxiety levels are higher in women than in men (10,15-17). Badner et al. (10) found that the anxiety level of mothers of children who will undergo surgery was higher, and this increase was attributed to the high anxiety level of women due to separation from their families. Shevde and Panagopoulos (17) found a higher anxiety level in women, which was attributed to their ability to express their mood easier than men. In a study by Messeri et al. (18), STAI was applied to parents who were allowed to be in the operating room during anesthesia. In this study, anxiety levels of mothers were higher than those of fathers. In our study, no significant relationship was observed between the sex of the parent and anxiety levels in both groups.

In the literature, studies on the relationship between education and anxiety levels have yielded variable results. As the education level of the parents increased, TAI scores significantly decreased, and no difference in SAI scores was observed (13). Similarly, in another study, parents with university level had low TAI scores (14). However, in a study showing contrasting results, general anxiety level increased as education level increased (19). In addition to these contradictory results, some studies showed no correlation between anxiety scores and education level (5). In our study, no difference was found between SAI and TAI scores and educational level of the parents of both groups, which may due to the social norms and cultural impact in our society being more effective, regardless of education level, in our behaviors and perspective on events. There are limited studies in the literature examining the effect of parental profession on parental anxiety. Senol (14) found that the anxiety level of the mothers who were housewives or belonging to lower occupational groups was higher, and they thought that this high level could be due to livelihood anxiety and stress factors. Similarly, in another study, the anxiety levels of mothers who were unemployed, housewives, or parents in lower occupational groups were higher than those in the middle and upper occupational groups (12). Our study found no statistically significant difference between the anxiety levels in the parents of both groups in different occupational groups, showing that our perspective on events is independent of education and profession. Our study found a statistically significant positive correlation between SAI and TAI scores of 
the parents in group NMS, showing that the parents in this group contributed to each other's anxiety levels. By contrast, no correlation was found between the parents in group MR.

Rates of consanguineous marriages remain at high levels in our country despite knowledge of its disadvantages. As a result of consanguineous marriage, the risk of developing many diseases, such as phenylketonuria that causes MR in children, increases. In our country, the rate of consanguineous marriages is still higher than the world average, and this situation causes hereditary transmission of MR diseases in children. In our study, consanguineous marriage was found in 14 of 40 patients in group MR and 9 of 60 patients in group NMS. The rate of consanguineous marriages was significantly higher in group MR, which support the idea that the risk of developing MR diseases in consanguineous marriages is high.

\section{CONCLUSION}

No significant correlation was found between MR and MR grade of the child and the parents' SAI and TAI scores in our study. Therefore, no relationship is observed between MR and parental anxiety levels. In addition, a positive correlation was found between SAI and TAI scores of the parents of patients with NMS, suggesting that parents in this group affected each other both in normal life and under stress conditions.

\section{Ethics}

Ethics Committee Approval: Our study was conducted in the operating room of the University of Health Sciences Bağcılar Training and Research Hospital after the approval of the Clinical Research Ethics Committee (decision no: 2018.05.02.049).

Informed Consent: Written informed consent of all participants was obtained.

Peer-review: Externally peer-reviewed.

\section{Authorship Contributions}

Surgical and Medical Practices: Y.E.C., Concept: S.D., F.G.Ö., A.S., Design: Y.E.C., S.D., F.G.Ö., Data Collection or Processing: Y.E.C., Analysis or Interpretation: S.D., Literature Search: Y.E.C., S.D., A.S., Writing: Y.E.C., S.D., F.G.Ö., A.S.

Conflict of Interest: No conflict of interest was declared by the authors.

Financial Disclosure: The authors declared that this study received no financial support.

\section{REFERENCES}

1. Dorantes DM, Tait AR, Naughton NN. Informed consent for obstetric anesthesia research: factors that influence parturients' decisions to participate. Anesth Analg 2000;91:369-73.

2. Bevan JC, Johnston C, Haig MJ, Tousignant G, Lucy S, Kirnon V et al. Preoperative parental anxiety predicts behavioural and emotional responses to induction of anaesthesia in children. Can J Anaesth 1990;37:177-82.

3. Cüceloğlu D. Insan ve Davranışları Psikolojisinin Temel Kavramları İstanbul: Remzi Kitabevi; 2005.

4. Egbert LD, Battit GE, Welch CE, Bartlett MK. Reduction of postoperative pain by encouragement and instruction of patients. N Engl J Med 1964;270:825-7.

5. Litman RS, Berger AA, Chhibber A. An evaluation of preoperative anxiety in a population of parents of infants and children undergoing ambulatory surgery. Pediatr Anaesth 1996;6:443-7.

6. Kain ZN, Wang SM, Caramico LA, Hofstadter M, Mayes LC. Parental desire for preoperative information and informedconsent: a two-phase study. Anaesth Analg 1997;84:299-306.

7. Shirley PJ, Thompson N, Kenward M, Johnston G. Parental anxiety before elective surgery in children. A British perspective. Anaesthesia 1998;53:956-9.

8. Semerci B. Bilinmezin kapısındaki çocuk ve aile: çocukların ve ailelerin cerrahi ișlemlere hazırlanması. Hacettepe Medical Journal 1999;30:226-8.

9. Sime AM. Relationship of preoperative fear, type of coping and information received about surgery to recovery from surgery. J Pers Soc Psychol 1976;34:716-24

10. Badner NH, Nielson WR, Munk S, Kwiatkowska C, Gelb AW. Preoperative anxiety: Detection and contributing factors. Can J Anaesth 1990;37:444-7.

11. Moerman N, Van Dam FS, Muller MJ, Oosting H. The Amsterdam preoperative anxiety and information scale (APAIS). AnaesthAnalg 1996;82:445-51.

12. AșıK K, Erbüyün K. The assesment of parental anxiety in pediatric surgery cases (dissertation). Celal Bayar University Medical Faculty Department of Anesthesiology and Reanimation. Manisa; 2012.

13. Güner B, Pamuk AG, Yazıcı MK, Aypar Ü. Informed Consent for an Anesthesia Study: How Does Timing Effect Parental Antiety Levels? Turkiye Klinikleri J Anest Reanim 2011;9:90-101.

14. Senol AV. The evaluation of parental anxiety of children who will receive general anesthesia (dissertation). Trakya University Medical Faculty Department of Anesthesiology and Reanimation. Edirne; 2013.

15. Valenzuella Millan J, Barrera Serrano JR, Ornelas Aguirre JM. Anxiety in preoperative anesthetic procedures. Cir Cir 2010;78:147-51.

16. Aykent R, Kocamanoğlu is, Üstün E, Tür A, Şahinoğlu H. Preoperatif anksiyete nedenleri ve değerlendirilmesi: APAIS ve STAI skorlarının karşılaștırılması. Türkiye Klinikleri J Anest Reanim 2007;5:7-13.

17. Shevde K, Panagopoulos G. A survey of 800 patients knowledge, attitudes and corncerns regarding ansthesia. Anesth Analg 1991;73:190-8.

18. Messeri A, Caprilli S, Busoni P. Anaesthesia induction in children: a psychological evaluation of the efficiency of parents presence. Pediatr Anaesth 2004;14:551-56

19. Demir A, Turan S, Balaban F, Karadeniz Ü, Erdemli Ö. Anestezi uygulamaları ile ilgili olarak preanestezik değerlendirme sırasında hastalarda yapılan anket çalıșması. Türk Anest Der 2009;37:225-33. 